GEOLOGY OF THE "20-FOOT" CLAY AND GARDINERS CLAY IN SOUTHERN NASSAU AND SOUTHWESTERN SUFFOLK COUNTIES, LONG ISLAND, NEW YORK

By Thomas P. Doriski and Franceska Wilde-Katz

U.S. GEOLOGICAL SURVEY

Water-Resources Investigations Report 82-4056

This document was prepared by the U.S. Geological Survey under a contract with Suffolk County and Nassau County, New York pursuant to 40 CFR, Part 30 and Part 35, Sub. E of the Federal Water Pollution Control Act, Construction Grants. This project has been financed in part with Federal funds from the United States Environmental Protection Agency under Grant No. C-36-10365-04. The contents do not necessarily reflect the views and policies of the U.S. Environmental Protection Agency nor does the mention of trade names or commercial products constitute endorsement or recommendations for use.

Prepared in cooperation with the

NASSAU COUNTY DEPARTMENT OF PUBLIC WORKS, and the

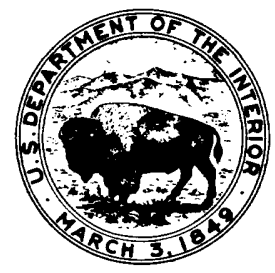

SUFFOLK COUNTY DEPARTMENT OF HEALTH SERVICES

Syosset, New York 


\section{UNITED STATES DEPARTMENT OF THE INTERIOR}

JAMES G. WATT, Secretary

GEOLOGICAL SURVEY

Dallas L. Peck, Director

For additional information write to:

Copies of this report can

U.S. Geological Survey

5 Aerial Way

Syosset, New York 11791

be purchased from:

Open-File Services Section Western Distribution $\mathrm{Br}$ anch

U. S. Geological Survey

Box 25425, Federal Center

Denver, Colo. 80225

Telephone: (303) 234-5888 


\section{CONTENTS}

Page

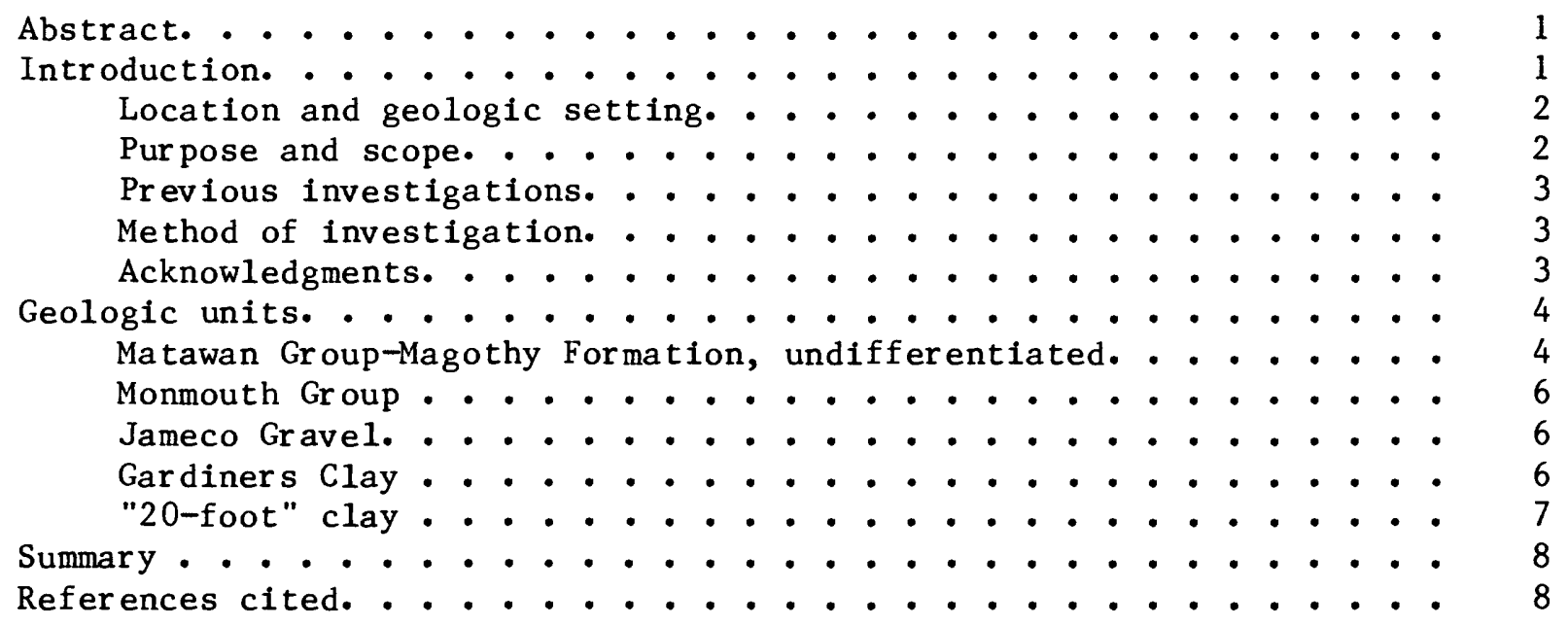

\section{ILLUSTRATION}

Figure 1. Map showing location of study area on Long Island. . . . .

\section{TABLES}

Table 1. Summary of stratigraphy and correlative hydrostratigraphy of deposits underlying southern Nassau and southwestern Suffolk Counties. . . . . . . . . . . . . . . . . .

2. Well depth and altitude data on selected wells in southern Nassau, southwestern Suffolk, and eastern Queens Counties . . 


\section{PLATES}

(in pocket)

Plate 1. Map showing locations of selected wells

2. Map showing surface altitude of Matawan Group-Magothy Formation, undifferentiated

3. Geologic sections $A-A^{\prime}, B-B^{\prime}, C-C^{\prime}, D-D^{\prime}$, and $E-E^{\prime}$

4. Map showing surface altitude of Monmouth Group and Jameco Gravel

5-6. Maps of Gardiners Clay showing:

5. Surface altitude

6. Thickness

7-8. Maps of "20-foot" clay showing:

7. Surface altitude

8. Thickness

FACTORS FOR CONVERTING INCH-POUND UNITS OF MEASURE

TO INTERNATIONAL SYSTEM OF UNITS (SI)

Multiply inch-pound units

foot ( $f t)$

mile (mi)
By

0.3048

1.609
To obtain SI units

meter ( $\mathrm{m}$ )

kilometer $(\mathrm{km})$ 


\title{
GEOLOGY OF THE "20-FOOT" CLAY AND GARDINERS CLAY IN SOUTHERN NASSAU AND SOUTHWESTERN SUFFOLK COUNTIES, LONG ISLAND, NEW YORK
}

\author{
by
}

Thomas P. Doriski and Franceska Wilde-Katz

\begin{abstract}
Data from 1978-79 drilling was compiled with information from previous reports and historical records to prepare surface-contour and isopach maps of the "20-foot" clay and Gardiners Clay in southern Nassau and southwestern Suffolk Counties. These units are major confining layers in the upper part of the ground-water reservoir along Long Island's south shore. Where present, they influence the ground-water flow patterns locally.

The "20-foot" clay, previously mapped in Nassau County only, was found in test borings in Suffolk County also. Its surface altitude ranges from 20 to 40 feet below NGVD (National Geodetic Vertical Datum of 1929); thickness ranges from 0 to 30 feet. The surface altitude of the Gardiners Clay ranges from 40 to 120 feet below NGVD; thickness ranges from 0 to 90 feet. Previously known discontinuities in both formations are more accurately delineated, and several new discontinuities have been inferred from the new data.

The Matawan Group-Magothy Formation undifferentiated, the Monmouth Group, and the Jameco Gravel directly underlie the Gardiners Clay. Revised surface altitudes of these formations are depicted on maps and cross sections of the south-shore area.
\end{abstract}

\section{INTRODUCTION}

In the late 1970's, the U.S. Geological Survey began a study to predict, by digital computer model, the impact of sanitary sewering on the ground-water reservoir in souther $\mathrm{n}$ Nassau and southwestern Suffolk Counties. To accurately predict the impact of hydrologic changes (such as sewering, pumping, or artificial recharge) on a ground-water reservoir, it is necessary to understand the geologic framework.

In 1978-79, the Survey conducted a drilling program to gain more complete information on the geologic framework of the system, especially the extent and thickness of two important confining units that strongly influence groundwater flow patterns in the upper part of the ground-water reservoir. 


\section{Location and Geologic Setting}

Southern Nassau County and adjacent southwestern Suffolk County are on Long Island's outwash plain, which extends about $10 \mathrm{mi}$ southward from the Ronkonkoma and Harbor Hill terminal moraines to the south shore. The south shore is characterized by swamps and lagoons bordering Great South Bay, which is in turn contained by the south-shore barrier islands (fig. 1).

Long Island is underlain by a thick sequence of unconsolidated Cretaceous and Pleistocene sediments extending from land surface to crystalline bedrock. These sediments contain the ground-water reservoir, the only source of freshwater for Nassau and Suffolk Counties. Along the south shore, the upper part of this sequence contains the two confining layers that were studied in detail--the "20-foot" clay and the Gardiners Clay.

\section{Purpose and Scope}

This report depicts in detail the areal extent, altitude, thickness, and lithology of the "20-foot" clay and Gardiners Clay (the two thickest and most extensive near-surface confining layers in the area) and redefines the surface of the geologic units that directly underlie these clay units at various locations--the Matawan Group-Magothy Formation, undifferentiated, the Monmouth Group, and the Jameco Gravel.

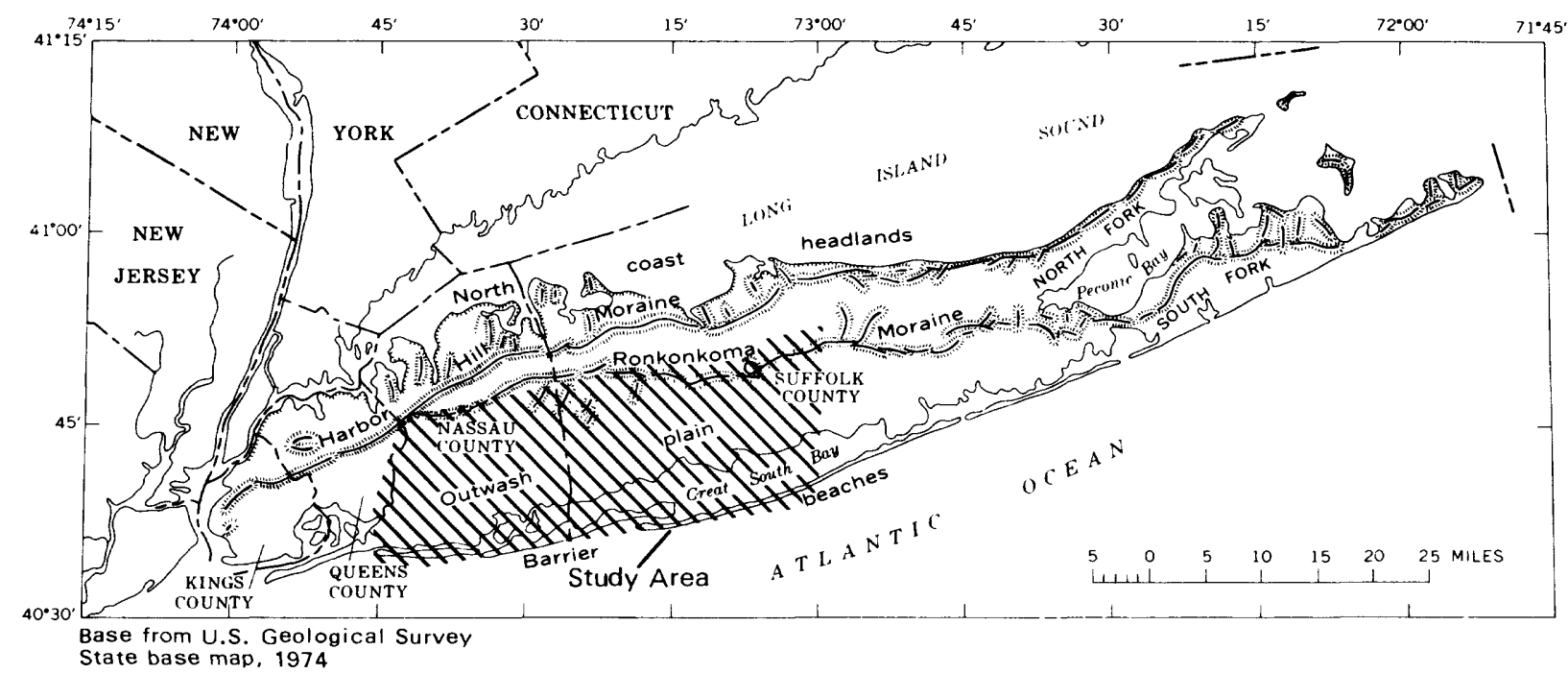

Figure 1.--Location of study area on Long Island, New York. (Modified from MCClymonds and Franke, 1972, p. 3.) 


\section{Previous Investigations}

Veatch and others (1906), Fuller (1914), and Suter and others (1949) mapped and described the geology of Long Island; Perlmutter and Crandell (1959) and Perlmutter and Todd (1965) described the hydrogeology of the south shore. Hydrogeologic and geologic information on western Suffolk County was updated by Soren (1971) and Jensen and Soren (1971, 1974); the information on Nassau County was updated by Perlmutter and Geraghty (1963) and Ku and others (1975).

\section{Method of Investigation}

A drilling program was conducted in 1978-79 to gain detailed geologic and hydrologic information on the "20-foot" clay and Gardiners Clay. (Locations of well borings are shown in pl. 1.) All test holes and wells in this program were drilled with standard or reverse rotary drilling rigs. Split spoon cores were taken at 5- to 10-ft intervals from just above the clay units to the underlying units. Wash samples were examined continuously during drilling. Geophysical logs (gamma-ray, resistivity, and spontaneous potential) were made at each site to supplement the core and wash-sample data. This information, supplemented by published data (previous hydrogeologic reports and surfaceextent maps) and we 11 records on file at the U.S. Geological Survey office in Syosset, N. Y., and the New York State Department of Environmental Conservation at Stony Brook, N. Y., was used to prepare the maps and cross sections herein.

A11 wells and test borings used in this report are listed in table 2 (at end of report), which also gives land-surface altitude and well depth to indicate which wells and borings are deep enough to be considered control points on the Gardiners Clay maps (pls. 5 and 6 ) in the areas of discontinuity. Some wells penetrated only the "20-foot" clay.

\section{Acknowledgments}

This report was prepared in cooperation with the New York State Department of Environmental Conservation, the Nassau-Suffolk Regional Planning Board, the Suffolk County Department of Health Services, the Nassau County Department of Public Works, and the U.S. Environmental Protection Agency. The authors extend thanks to Geraghty and Miller, Inc., and R. E. Wright Associates, Inc., for their assistance in establishing and supervising the drilling programs, and to Layne-New York, Strata We11, and Delta Well drilling companies for their assistance in obtaining geological and geophysical information. 


\section{GEOLOGIC UNITS}

The geologic units and corresponding hydrogeologic units that form the ground-water reservoir of Long Island, and their stratigraphic relationships, are summarized in table 1. The following sections describe the composition, extent, altitude, and thickness of the "20-foot" clay and the Gardiners Clay and the extent and altitude of the units directly underlying them. The unit descriptions are given in order of deposition, from oldest to youngest.

\section{Matawan Group-Magothy Formation, Undifferentiated}

The Matawan Group-Magothy Formation, undifferentiated, is a deltaic deposit of Cretaceous age that extends throughout the area studied. Its upper surface altitude ranges from 250 to $-500 \mathrm{ft}$ NGVD ( $\mathrm{pl}$. 2); thickness ranges from $400 \mathrm{ft}$ at the northern extent of the study area to $900 \mathrm{ft}$ beneath the south shore. The Matawan Group-Magothy Formation disconformably overlies the Raritan Formation and is disconformably overlain by the Monmouth Group, the Jameco Gravel, the Gardiners Clay, or upper Pleistocene deposits, depending on location. The Matawan Group-Magothy Formation is typically a gray and white, fine to coarse sand with some interstitial clay. Detailed lithologic descriptions are given in Soren (1978); Ku and others (1975); and Jensen and Soren (1974).

The upper surface of the Matawan Group-Magothy Formation is depicted in the cross sections in plate 3. One area of the Matawan Group-Magothy Formation surface that is of particular interest in relation to the Gardiners Clay is the valley in the triangular area bounded by Veterans Memorial Highway, Sunrise Highway, and Connetquot River in Suffolk County (pls. 2 and 3 , cross sections $B-B^{\prime}$ and $C^{-C^{\prime}}$; wells 65340 and $67074, \mathrm{p} 1.1$ ). No deep-well data have as yet been obtained from this valley south of Sunrise Highway; therefore, interpretation of the position of the overlying units is somewhat tentative.

In this report, the valley is interpreted as post-Cretaceous and may be related to a Pliocene erosion interval described by Veatch (1906, p. 32, p1. 6a). Veatch shows a drainage channel from Connecticut crossing Long Island in the same area as the valley shown on plate 2. (The valley beneath Lake Ronkonkoma may also be connected to the valley south of Veterans Memorial Highway.) If the valley was formed during a Pliocene erosion interval, the Monmouth Group and the upper surface of the Matawan Group-Magothy Formation (both Cretaceous) were eroded away. After this erosion period, the valley was probably filled in with channel deposits. Driller's and geologist's logs, as well as geophysical logs from wells 65340, 67074, and 68690 (not included in p1. 1 because of proximity to 65340) indicate that the deposits from -130 to $-270 \mathrm{ft}$ NGVD are different from typical Pleistocene outwash deposits and may be a localized Pliocene or Pleistocene (pre-Sangamon) channel deposit. If this interpretation is correct, the Gardiners Clay is continuous and relatively uniform over this area, which is important if it is to act as a confining layer. 
Table 1.--Summary of stratigraphy and correlative hydrostratigraphy of deposits underlying southern Nassau and southwestern Suffolk Counties, New York

\begin{tabular}{|c|c|c|c|c|c|}
\hline System & Series & Age & \multicolumn{2}{|c|}{ Stratigraphic Unit } & $\begin{array}{c}\text { Hydrostratigraphic } \\
\text { Unit }\end{array}$ \\
\hline \multirow{6}{*}{ QUATERNARY } & Holocene & Postglacial & $\begin{array}{r}\text { Holocene } \\
\text { depc }\end{array}$ & $\begin{array}{l}\text { (ecent) } \\
\text { ts }\end{array}$ & Upper \\
\hline & \multirow{5}{*}{ Pleistocene } & \multirow{3}{*}{$\begin{array}{c}\text { Wisconsin } \\
\text { (upper } \\
\text { Pleistocene) }\end{array}$} & \multicolumn{2}{|c|}{$\begin{array}{c}\text { Upper } \\
\text { Pleistocene } \\
\text { deposits }\end{array}$} & $\begin{array}{l}\text { glacial } \\
\text { aquifer }\end{array}$ \\
\hline & & & \multicolumn{2}{|c|}{ "20-foot" clay } & "20-foot" clay \\
\hline & & & \multicolumn{2}{|c|}{$\begin{array}{l}\text { Upper Pleistocene } \\
\text { deposits } \\
\text { unconformity }\end{array}$} & $\begin{array}{l}\text { Upper glacial } \\
\text { aquifer }\end{array}$ \\
\hline & & Sangamon & \multicolumn{2}{|c|}{$\begin{array}{l}\text { Gardiners Clay } \\
\text { unconformity }\end{array}$} & Gardiners Clay \\
\hline & & $\begin{array}{c}\text { Pre-Sangamon } \\
\text { (I1linolan or Kansan) }\end{array}$ & \multicolumn{2}{|c|}{ Jameco Grave $1^{1}$} & Jameco aquifer ${ }^{1}$ \\
\hline $\begin{array}{c}\text { Quaternary } \\
\text { and Tertiary } \\
\text { undifferen- } \\
\text { tiated }\end{array}$ & & $\begin{array}{l}\text { Pre-Sangamon to } \\
\text { Post-Cretaceous, } \\
\text { undifferen- } \\
\text { tiated }\end{array}$ & \multicolumn{2}{|c|}{$\begin{array}{c}\text { Reworked Matawan- } \\
\text { Magothy channel } \\
\text { deposits }\end{array}$} & $\begin{array}{l}\text { Upper glacial or } \\
\text { Magothy aquifer }\end{array}$ \\
\hline \multirow{4}{*}{ CRETACEOUS } & \multirow{4}{*}{$\begin{array}{c}\text { Upper } \\
\text { Cretaceous }\end{array}$} & & \multicolumn{2}{|c|}{$\begin{array}{c}\text { Monmouth } \\
\text { Group } \\
\text { unconformity }\end{array}$} & $\begin{array}{l}\text { Monmouth } \\
\text { greensand }\end{array}$ \\
\hline & & & \multicolumn{2}{|c|}{$\begin{array}{l}\text { Matawan Group- } \\
\text { Magothy Formation, } \\
\text { undifferentiated } \\
\text { unconformity }\end{array}$} & $\begin{array}{l}\text { Magothy } \\
\text { aquifer }\end{array}$ \\
\hline & & & \multirow[t]{2}{*}{$\begin{array}{l}\text { Raritan } \\
\text { Formation }\end{array}$} & $\begin{array}{l}\text { Unnamed } \\
\text { clay } \\
\text { member }\end{array}$ & $\begin{array}{c}\text { Raritan } \\
\text { confining unit }\end{array}$ \\
\hline & & & & $\begin{array}{l}\text { Lloyd } \\
\text { Sand } \\
\text { Member }\end{array}$ & Lloyd aquifer \\
\hline \multicolumn{3}{|c|}{ Precambrian } & \multicolumn{2}{|c|}{ Bedrock } & $\begin{array}{l}\text { Relatively } \\
\text { Impermeable } \\
\text { bedrock }\end{array}$ \\
\hline
\end{tabular}




Two other interpretations are that (1) all units were deposited, then eroded, by a glacial meltwater stream of Wisconsin age, or (2) the valley was formed during the Cretaceous, so that the Monmouth Group and Gardiners Clay overlying it contain corresponding valleys. In either case, the Gardiners Clay would be discontinuous and not function as a confining layer in this area.

\section{Monmouth Group}

The Monmouth Group is a marine deposit of Cretaceous age that occurs along the barrier islands primarily in Suffolk County. Its upper surface altitude ranges from -70 to $-165 \mathrm{ft}$ NGVD (pls. 3, 4); thickness ranges from 0 to $200 \mathrm{ft}$. The Monmouth Group disconformably overlies the Matawan GroupMagothy Formation and is disconformably overlain by the Gardiners Clay. The Monmouth Group is typically a greenish-black glauconitic and lignitic clay, silt, or clayey to silty sand. A more detailed lithologic description of the Monmouth Group is given in Jensen and Soren (1974).

\section{Jameco Gravel}

The Jameco Gravel, a stream deposit, is pre-Sangamon, possibly of Illinoian or Kansan age (Soren, 1978). It occurs primarily in Queens County but extends into the extreme southwestern part of Nassau County, where its upper surface altitude ranges from -80 to $-140 \mathrm{ft}$ NGVD (pls. 3, 4) and thickness ranges from 0 to $100 \mathrm{ft}$. It disconformably overlies the Matawan Group-Magothy Formation and is disconformably overlain by the Gardiners Clay. The Jameco Gravel is typically a dark brown and dark gray granule to cobble gravel. The depositional history and a more detailed lithologic description of the Jameco Gravel are given in Soren (1978).

\section{Gardiners Clay}

The Gardiners Clay is a marine deposit along the south shore of Long Island. In southern Nassau County and southwestern Suffolk County, its upper surface altitude ranges from -40 to $-120 \mathrm{ft}$ NGVD (p1s. 3, 5); thickness ranges from $0 \mathrm{ft}$ at the northern limit to $90 \mathrm{ft}$ at the barrier islands (p1s. 3,6). The deposit disconformably overlies either the Matawan Group-Magothy Formation, the Monmouth Group, or the Jameco Gravel, depending on location, and is disconformably overlain by upper Pleistocene deposits.

The age of the Gardiners Clay exceeds 38,000 years, according to carbon-14 dating tests on oyster shells found in the unit at two localities in Nassau County (Swarzenski, 1963, p. 20). As a result of this dating, as well as the stratigraphic position of this unit, the Gardiners Clay has been considered to be of Sangamon age (Soren, 1971, p. 15).

The Gardiners Clay is typically grayish-green to gray and contains a few sand and silt beds, which generally make up less than 10 percent of the total thickness of the unit in a specific area. The mineral assemblage commonly contains glauconite, quartz, muscovite, biotite, pyroxene, amphibole, and a complete clay mineral suite of illite, chlorite, mixed-layer clays, and minor 
kaolinite (Lonnie, 1982). The clay also contains diatoms, foraminifera, shell fragments of pelecypods and gastropods, and peat. A more detailed discussion of the Gardiners Clay is given in Perlmutter and Geraghty (1963, p. A32-A35).

The surface of the Gardiners Clay in plate 5 is a revision of the areal-extent maps by Perlmutter and Geraghty (1963, p. 33A) and Jensen and Soren (1974). The major difference between plate 5 and those maps is the improved delineation of the unit's absence in long, narrow north-south channels along the south shore (pls. 5, 6). These absences probably correspond to areas of erosion by glacial meltwater streams and areas of nondeposition. Although the Gardiners Clay is generally continuous along the south shore, these areas are delineated because of their hydrologic importance in influencing the ground-water flow patterns. Where the clay is absent, the upper aquifer has good hydraulic connection with the lower aquifer; where the clay is present, the upper aquifer has poor hydraulic connection with the lower aquifer. This discontinuity and other discrepancies between plates 5 and 6 and earlier maps were determined through the 1978-79 drilling program and the correlation of unpublished well and test-hole data.

The thickness of the Gardiners Clay (pl. 6) is hydrologically important because it largely controls the water-transmitting property of the clay. The thickness of the formation increases southward to the barrier islands. In some areas along the south shore, the lower several feet of the Gardiners Clay may contain a sand or gravel facies. These facies are included as part of the clay unit in the geologic isopach map (pl. 6) but are not represented in the Geological Survey's ground-water model developed by Reilly and others (written commun., 1981) because they are not confining.

\section{"20-Foot" Clay}

The "20-foot" clay is a marine deposit within the upper Pleistocene deposits near the south shore. Its upper surface altitude ranges from -20 to $-40 \mathrm{ft}$ NGVD (pls. 3, 7); thickness ranges from $0 \mathrm{ft}$ at the northern limit to $30 \mathrm{ft}$ at the barrier islands ( $1 \mathrm{~s} .3,8$ ). The unit overlies upper Pleistocene deposits that range in thickness from 2 to $40 \mathrm{ft}$ and is overlain by upper Pleistocene deposits. The "20-foot" clay was probably deposited during an interstadial period in the Wisconsin glaciation (table 1). The upper Pleistocene deposits underlying the "20-foot" clay are generally a light brown, fine to medium-grained sand (although drillers' logs report some gravel), and are considered to be outwash deposits. The deposits that overlie the "20-foot" clay are also outwash but, in general, are brown, coarser grained, and contain more gravel. The "20-foot" clay directly overlies the Matawan Group-Magothy Formation or Gardiners Clay at several locations where the upper Pleistocene deposits have been removed by erosion. (See pl. 3, well N-5227 near Jones Inlet.)

The surface of the "20-foot" clay in plate 7 is revised from the areal-extent map by Perlmutter and Geraghty (1963, p. 33A) and shows the discontinuity of the clay layer (absences of the unit in narrow, nor th-south channels) in greater detail. Previous reports do not indicate the "20-foot" clay to extend into Suffolk County, but data obtained during the 1978-79 drilling program indicate it to be present on the barrier island in Suffolk County (p1. 7). 
The "20-foot" clay is lithologically similar to the Gardiners Clay, with the same mineral assemblage and fossils. In this study, the "20-foot" clay and Gardiners Clay were identified primarily by stratigraphic position. Their correlation in western Nassau County was relatively easy because they are separated by 15 to $40 \mathrm{ft}$ of upper Pleistocene deposits; in eastern Nassau County, however, they are separated by a smaller thickness of upper Pleistocene deposits ( 2 to $15 \mathrm{ft}$ ), and the correlations in this area are more tentative.

\section{SUMMARY}

A drilling program conducted during 1978-79 provided new hydrologic and geologic information on the "20-foot" clay and Gardiners Clay that enabled revision of previous maps. The new surface-altitude and isopach maps depict the extent of the two units in greater detail than previous reports, especially the discontinuities in the general area of deposition along the south shore of Long Island. The "20-foot" clay, which was previously reported and mapped in Nassau County only, was encountered in some of the well borings in Suffolk County. The new information also allowed revision of the topography of the underlying units in contact with these clay layers--the Matawan Group-Magothy Formation, Monmouth Group and the Jameco Gravel.

\section{REFERENCES CITED}

Fuller, M. L., 1914, The geology of Long Island, New York: U.S. Geological Survey Professional Paper 82, 231 p.

Jensen, H. M., and Soren, Julian, 1971, Hydrogeologic data from selected wells and test holes in Suffolk County, Long Island, New York: Suffolk County Department of Environmental Control, Long Island Water Resources Bulletin $3,35 \mathrm{p}$.

, 1974, Hydrogeology of Suffolk County, Long Island, New York: U.S. Geological Survey Hydrologic Investigation Atlas HA-501, 2 sheets.

Ku, H. F. H., Vecchioli, John, and Cerrillo, L. A., 1975, Hydrogeology along the proposed barrier-recharge-well alinement in southern Nassau County, Long Island, New York: U.S. Geological Survey Hydrologic Investigation At las HA-502, 1 sheet.

Lonnie, T. P., 1982, Mineral and chemical composition of clay beds on the south shore of Long Island, New York: Journal of Sedimentary Petrology, v. 52, no. 2 , p. 529-536.

McClymonds, N. E., and Franke, O. L., 1972, Water-transmitting properties of aquifers on Long Island, New York: U.S. Geological Survey Professional Paper 627-E, p. E1-E24. 


\section{REFERENCES CITED (continued)}

Perlmutter, N. M., and Crande11, H. C., 1959, Geology and ground-water supplies of the south-shore beaches of Long Island, New York: New York Academy of Science Annals, v. 80, art. 4, p. 1060-1076.

Perlmutter, N. M., and Geraghty, J. J., 1963, Geology and ground-water conditions in southern Nassau and southeastern Queens Counties, Long Island, New York: U.S. Geological Survey Water-Supply Paper 1613-A, 205 p.

Perlmutter, N. M., and Todd, Ruth, 1965, Correlation and foraminifera of the Monmouth Group (Upper Cretaceous), Long Island, N. Y.: U. S. Geological Survey Professional Paper 483-I, 24 p.

Soren, Julian, 1971, Results of subsurface exploration in the mid-island area of western Suffolk County, Long Island, New York: Suffolk County Water Authority, Long Island Water Resources Bulletin 1, 60 p.

, 1978, Subsurface geology and paleogeography of Queens County, Long Island, New York: U.S. Geological Survey Water-Resources Investigation, Open-file report $77-34,17 \mathrm{p}$.

Suter, Russe11, delaguna, Wallace, and Perlmutter, N. M., 1949, Mapping of geologic formations and aquifers of Long Island, New York: New York State Water Power and Control Commission Bulletin GW-18, 212 p.

Swarzenski, W. V., 1963, Hydrogeology of nor thwestern Nassau and nor theastern Queens County, Long Island, New York: U. S. Geological Survey WaterSupply Paper 1657, 90 p.

Veatch, A. C., Slichter, C. S., Bowman, Isaiah, Crosby, W. O. , and Horton, R. E., 1906, Underground water resources of Long Island, New York: U.S. Geological Survey Professional Paper 44, 394 p. 
Table 2.--Well depth and altitude data on selected wells in southern Nassau, southwestern Suffolk, and eastern Queens Counties, New York

[Altitudes are feet above NGVD of 1929; depths are feet below land-surface altitude.

$N$, Nassau; Q, Queens; S, Suffolk]

\begin{tabular}{|c|c|c|c|c|c|c|}
\hline \multicolumn{2}{|c|}{$\begin{array}{l}\text { Well } \\
\text { no. }\end{array}$} & \multirow{2}{*}{$\begin{array}{l}\begin{array}{c}\text { Land- } \\
\text { surface }\end{array} \\
\text { altitude } \\
19\end{array}$} & \multirow{2}{*}{$\begin{array}{c}\begin{array}{l}\text { We11 } \\
\text { depth }\end{array} \\
82\end{array}$} & $\begin{array}{l}\text { We11 } \\
\text { no. }\end{array}$ & \multirow{2}{*}{$\begin{array}{l}\begin{array}{c}\text { Land- } \\
\text { surface }\end{array} \\
\text { altitude } \\
55\end{array}$} & \multirow{2}{*}{$\begin{array}{r}\begin{array}{r}\text { We11 } \\
\text { depth }\end{array} \\
67\end{array}$} \\
\hline $\mathrm{N}$ & 2 & & & N $\quad 941$ & & \\
\hline $\mathrm{N}$ & 3 & 5 & 465 & $\mathrm{~N} \quad 1038$ & 60 & 115 \\
\hline $\mathrm{N}$ & 6 & 15 & 338 & N 1335 & 25 & 142 \\
\hline $\mathrm{N}$ & 17 & 104 & 470 & N 1346 & 5 & 148 \\
\hline $\mathrm{N}$ & 47 & 6 & 182 & N 1499 & 6 & 245 \\
\hline $\mathrm{N}$ & 48 & 17 & 523 & N 1585 & 65 & 88 \\
\hline $\mathrm{N}$ & 54 & 28 & 101 & N 1602 & 30 & 593 \\
\hline $\mathrm{N}$ & 57 & 11 & 150 & N 1658 & 115 & 300 \\
\hline $\mathrm{N}$ & 62 & 10 & 200 & N 1742 & 20 & 272 \\
\hline $\mathrm{N}$ & 69 & 21 & 505 & N 1744 & 20 & 77 \\
\hline $\mathrm{N}$ & 72 & 45 & 616 & $\mathrm{~N} 1869$ & 10 & 132 \\
\hline $\mathrm{N}$ & 73 & 30 & 716 & $\mathrm{~N} 1922$ & 125 & 191 \\
\hline $\mathrm{N}$ & 93 & 75 & 82 & N 1927 & 10 & 1,471 \\
\hline $\mathrm{N}$ & 101 & 108 & 399 & N 1958 & 113 & 754 \\
\hline $\mathrm{N}$ & 130 & 5 & 68 & N 2006 & 45 & 63 \\
\hline $\mathrm{N}$ & 134 & 15 & 556 & N 2064 & 5 & 71 \\
\hline $\mathrm{N}$ & 135 & 20 & 150 & N 2203 & 5 & 182 \\
\hline $\mathrm{N}$ & 136 & 25 & 122 & N 2225 & 5 & 174 \\
\hline $\mathrm{N}$ & 137 & 10 & 90 & N 2349 & 55 & 106 \\
\hline $\mathrm{N}$ & 138 & 25 & 125 & N 2359 & 5 & 63 \\
\hline $\mathrm{N}$ & 140 & 55 & 156 & N 2400 & 166 & 487 \\
\hline $\mathrm{N}$ & 141 & 28 & 109 & N 2413 & 52 & 526 \\
\hline $\mathrm{N}$ & 184 & 10 & 161 & N 2572 & 5 & 100 \\
\hline $\mathrm{N}$ & 185 & 45 & 272 & N 2574 & 20 & 544 \\
\hline $\mathrm{N}$ & 248 & 15 & 190 & N 2580 & 75 & 76 \\
\hline $\mathrm{N}$ & 319 & 10 & 386 & N 2597 & 6 & 1,244 \\
\hline $\mathrm{N}$ & 320 & 5 & 383 & N 2921 & 8 & 120 \\
\hline $\mathrm{N}$ & 440 & 8 & 80 & N 3078 & 5 & 146 \\
\hline $\mathrm{N}$ & 559 & 25 & 150 & N 3147 & 121 & 250 \\
\hline $\mathrm{N}$ & 578 & 110 & 415 & $\mathrm{~N} 3185$ & 100 & 499 \\
\hline $\mathrm{N}$ & 629 & 55 & 71 & N 3193 & 85 & 320 \\
\hline $\mathrm{N}$ & 637 & 5 & 187 & N 3197 & 20 & 48 \\
\hline $\mathrm{N}$ & 647 & 12 & 44 & N 3245 & 5 & 215 \\
\hline $\mathrm{N}$ & 693 & 90 & 107 & N 3312 & 70 & 307 \\
\hline $\mathrm{N}$ & 914 & 10 & 114 & N 3325 & 5 & 120 \\
\hline
\end{tabular}


Table 2.--Well depth and altitude data on selected wells in southern Nassau, southwestern Suffolk, and eastern Queens Counties, New York (continued)

\begin{tabular}{|c|c|c|c|c|c|}
\hline $\begin{array}{l}\text { Well } \\
\text { no. }\end{array}$ & $\begin{array}{l}\text { Land- } \\
\text { surface } \\
\text { altitude }\end{array}$ & $\begin{array}{l}\text { We } 11 \\
\text { depth }\end{array}$ & $\begin{array}{l}\text { Well } \\
\text { no. }\end{array}$ & $\begin{array}{l}\text { Land- } \\
\text { surface } \\
\text { altitude }\end{array}$ & $\begin{array}{l}\text { Well } \\
\text { depth }\end{array}$ \\
\hline N 3355 & 183 & 1,248 & N 3905 & 130 & 770 \\
\hline N 3448 & 7 & 1,250 & N 3926 & 14 & 115 \\
\hline N 3465 & 80 & 562 & N 3937 & 25 & 677 \\
\hline N 3479 & 30 & 72 & N 4077 & 76 & 538 \\
\hline N 3488 & 117 & 351 & N 4095 & 150 & 527 \\
\hline N 3520 & 30 & 475 & N 4120 & 35 & 458 \\
\hline N 3529 & 10 & 106 & $\mathrm{~N} 4149$ & 5 & 878 \\
\hline N 3581 & 8 & 57 & N 4150 & 7 & 826 \\
\hline N 3603 & 75 & 533 & N 4334 & 65 & 161 \\
\hline N 3605 & 48 & 585 & N 4382 & 114 & 220 \\
\hline N 3618 & 88 & 420 & N 4411 & 17 & 568 \\
\hline N 3636 & 50 & 356 & N 4425 & 60 & 375 \\
\hline N 3653 & 15 & 47 & N 4512 & 35 & 522 \\
\hline N 3668 & 55 & 566 & N 4516 & 10 & 62 \\
\hline N 3685 & 55 & 150 & N 4657 & 15 & 72 \\
\hline N 3704 & 55 & 200 & N 4875 & 25 & 148 \\
\hline N 3705 & 24 & 190 & N 5079 & 10 & 153 \\
\hline N 3720 & 35 & 586 & N 5112 & 18 & 57 \\
\hline N 3721 & 40 & 101 & N 5145 & 30 & 504 \\
\hline N 3734 & 10 & 140 & N 5149 & 147 & 192 \\
\hline N 3741 & 20 & 122 & N 5153 & 25 & 355 \\
\hline N 3758 & 110 & 100 & N 5187 & 35 & 614 \\
\hline N 3855 & 20 & 42 & N 5227 & 10 & 1,288 \\
\hline N 3861 & 7 & 623 & N 5233 & 12 & 549 \\
\hline N 3862 & 7 & 310 & N 5260 & 55 & 518 \\
\hline N 3863 & 11 & 217 & N 5292 & 5 & 92 \\
\hline N 3864 & 5 & 636 & N 5301 & 107 & 504 \\
\hline N 3865 & 4 & 850 & N 5302 & 65 & 490 \\
\hline N 3866 & 6 & 452 & N 5303 & 60 & 515 \\
\hline N 3867 & 6 & 550 & N 5304 & 55 & 503 \\
\hline N 3876 & 90 & 406 & N 5368 & 130 & 150 \\
\hline N 3878 & 150 & 607 & N 5484 & 90 & 579 \\
\hline N 3881 & 80 & 494 & N 5524 & 5 & 144 \\
\hline N 3894 & 30 & 415 & N 5654 & 102 & 335 \\
\hline N 3895 & 40 & 503 & N 5655 & 130 & 260 \\
\hline
\end{tabular}


Table 2.--Well depth and altitude data on selected wells in southern Nassau, southwestern Suffolk, and eastern Queens Counties, New York (continued)

\begin{tabular}{|c|c|c|c|c|c|}
\hline $\begin{array}{l}\text { Well } \\
\text { no. }\end{array}$ & $\begin{array}{l}\text { Land- } \\
\text { surface } \\
\text { altitude }\end{array}$ & $\begin{array}{l}\text { We1l } \\
\text { depth }\end{array}$ & $\begin{array}{l}\text { Well } \\
\text { no. }\end{array}$ & $\begin{array}{l}\text { Land- } \\
\text { surface } \\
\text { altitude }\end{array}$ & $\begin{array}{r}\text { Well } \\
\text { depth }\end{array}$ \\
\hline N 5705 & 145 & 513 & N 6644 & 90 & 238 \\
\hline $\mathrm{N} \quad 5731$ & 15 & 102 & $\mathrm{~N} \quad 6651$ & 225 & 620 \\
\hline N 5768 & 5 & 850 & N 6657 & 5 & 411 \\
\hline N 5777 & 5 & 83 & $\mathrm{~N} 6660$ & 15 & 88 \\
\hline N 5795 & 10 & 47 & N 6706 & 6 & 743 \\
\hline N 5906 & 10 & 111 & N 6741 & 180 & 423 \\
\hline N 5975 & 12 & 63 & $\mathrm{~N} 6757$ & 5 & 71 \\
\hline N 6004 & 10 & 67 & $\mathrm{~N} 6769$ & 10 & 72 \\
\hline $\mathrm{N} \quad 6046$ & 101 & 356 & $\mathrm{~N} 6780$ & 5 & 66 \\
\hline N 6075 & 10 & 111 & N 6791 & 5 & 78 \\
\hline N 6077 & 150 & 467 & $\mathrm{~N} 6813$ & 10 & 238 \\
\hline N 6093 & 240 & 606 & N 6817 & 28 & 578 \\
\hline N 6148 & 50 & 566 & N 6819 & 130 & 262 \\
\hline$N \quad 6149$ & 47 & 717 & N 6834 & 25 & 703 \\
\hline N 6150 & 59 & 704 & N 6848 & 110 & 112 \\
\hline $\mathrm{N} \quad 6191$ & 180 & 676 & N 6893 & 40 & 564 \\
\hline N 6192 & 127 & 657 & $\mathrm{~N} 6915$ & 90 & 586 \\
\hline N 6202 & 132 & 264 & $\mathrm{~N} \quad 6929$ & 10 & 35 \\
\hline N 6315 & 104 & 355 & N 6956 & 170 & 654 \\
\hline N 6354 & 10 & 114 & N 6965 & 5 & 137 \\
\hline N 6355 & 5 & 130 & N 6992 & 24 & 111 \\
\hline N 6376 & 200 & 247 & N 6996 & 132 & 120 \\
\hline N 6384 & 5 & 82 & N 7022 & 60 & 64 \\
\hline N 6437 & 65 & 291 & $\mathrm{~N} 7030$ & 160 & 538 \\
\hline N 6442 & 31 & 612 & N 7114 & 9 & 202 \\
\hline $\mathrm{N} \quad 6043$ & 16 & 46 & N 7117 & 60 & 491 \\
\hline $\mathrm{N} 6450$ & 10 & 1,331 & $\mathrm{~N} 7124$ & 70 & 155 \\
\hline N 6455 & 15 & 84 & $\mathrm{~N} 7133$ & 9 & 150 \\
\hline $\mathrm{N} \quad 6467$ & 4 & 698 & N 7160 & 60 & 699 \\
\hline N 6468 & 5 & 704 & N 7161 & 10 & 700 \\
\hline N 6469 & 5 & 703 & N 7353 & 120 & 415 \\
\hline N 6580 & 160 & 702 & N 7377 & 65 & 766 \\
\hline N 6610 & 10 & 230 & $\mathrm{~N} 7433$ & 25 & 95 \\
\hline $\mathrm{N} 6623$ & 20 & 138 & N 7469 & 20 & 278 \\
\hline N 6636 & 60 & 200 & N 7482 & 35 & 460 \\
\hline
\end{tabular}


rable 2.--Well depth and altitude data on selected wells in southern Nassau, southwestern Suffolk, and eastern Queens Counties, New York (continued)

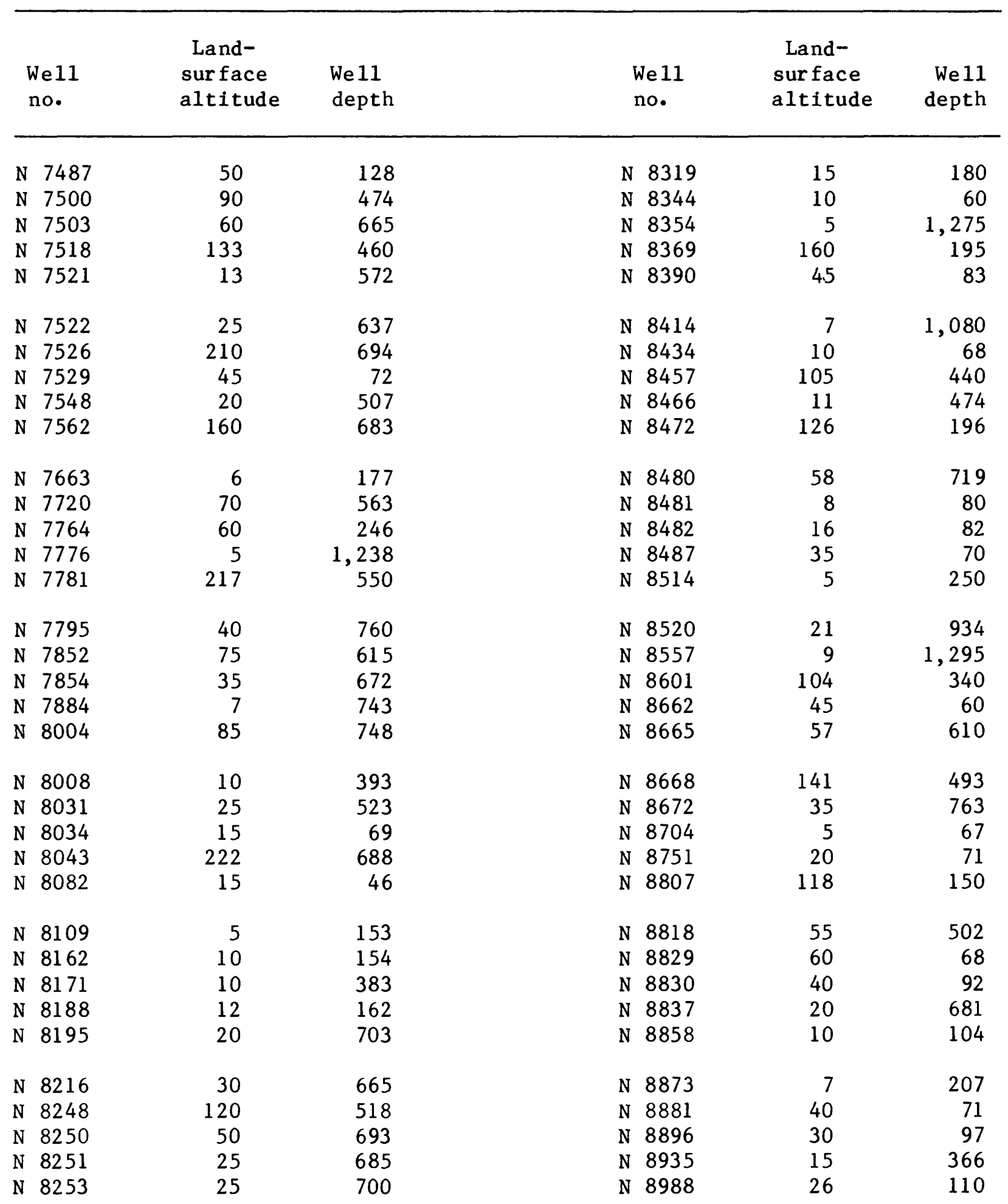


Table 2.--Well depth and altitude data on selected wells in southern Nassau, southwestern Suffolk, and eastern Queens Counties, New York (continued)

\begin{tabular}{|c|c|c|c|c|c|}
\hline $\begin{array}{l}\text { We11 } \\
\text { no. }\end{array}$ & $\begin{array}{l}\text { Land- } \\
\text { sur face } \\
\text { altitude }\end{array}$ & $\begin{array}{l}\text { We11 } \\
\text { depth }\end{array}$ & $\begin{array}{l}\text { We11 } \\
\text { no. }\end{array}$ & $\begin{array}{l}\text { Land- } \\
\text { surface } \\
\text { altitude }\end{array}$ & $\begin{array}{r}\text { Well } \\
\text { depth }\end{array}$ \\
\hline N 9173 & 38 & 884 & Q 2426 & 10 & 244 \\
\hline N 9234 & 105 & 205 & Q 2955 & 25 & 455 \\
\hline N 9318 & 55 & 462 & Q 3056 & 40 & 469 \\
\hline N 9523 & 20 & 138 & S 12 & 7 & 315 \\
\hline N 9532 & 10 & 140 & 15 & 40 & 101 \\
\hline N 9533 & 10 & 145 & 16 & 20 & 129 \\
\hline N 9534 & 20 & 85 & 17 & 50 & 125 \\
\hline N 9535 & 5 & 105 & 18 & 56 & 400 \\
\hline N 9536 & 5 & 80 & 19 & 130 & 203 \\
\hline N 9537 & 28 & 68 & 24 & 150 & 132 \\
\hline N 9538 & 10 & 145 & 37 & 33 & 820 \\
\hline N 9539 & 6 & 60 & 42 & 120 & 1,008 \\
\hline N 9541 & 28 & 105 & 58 & 38 & 468 \\
\hline N 9550 & 15 & 125 & 74 & 10 & 111 \\
\hline N 9551 & 10 & 95 & 78 & 41 & 121 \\
\hline N 9552 & 15 & 95 & 88 & 40 & 116 \\
\hline N 9553 & 5 & 85 & 92 & 15 & 180 \\
\hline N 9554 & 20 & 100 & 95 & 26 & 463 \\
\hline N 9556 & 20 & 155 & S 375 & 25 & 140 \\
\hline N 9565 & 40 & 100 & S 731 & 85 & 129 \\
\hline N 9567 & 25 & 140 & S 1052 & 5 & 97 \\
\hline N 9576 & 15 & 75 & S 1296 & 240 & 216 \\
\hline N 9577 & 25 & 80 & S 1370 & 10 & 375 \\
\hline N 9579 & 55 & 185 & S 1793 & 320 & 273 \\
\hline N 9643 & 20 & 70 & S 1801 & 200 & 175 \\
\hline N 9683 & 25 & 65 & S 1834 & 10 & 304 \\
\hline N 9684 & 20 & 70 & S 2314 & 80 & 480 \\
\hline N 9685 & 15 & 80 & S 2424 & 110 & 150 \\
\hline N 9792 & 31 & 562 & S 2459 & 10 & 131 \\
\hline Q 568 & 60 & 869 & S 4761 & 5 & 530 \\
\hline Q 720 & 25 & 406 & S 5134 & 175 & 160 \\
\hline Q 721 & 15 & 412 & S 5670 & 230 & 183 \\
\hline Q 1815 & 55 & 306 & S 5716 & 200 & 159 \\
\hline Q 1958 & 50 & 442 & S 5869 & 200 & 191 \\
\hline Q 2259 & 50 & 374 & S 6187 & 5 & 310 \\
\hline
\end{tabular}


Table 2.--Well depth and altitude data on selected wells in southern Nassau, southwestern Suffolk, and eastern Queens Counties, New York (continued)

\begin{tabular}{|c|c|c|c|c|c|}
\hline $\begin{array}{l}\text { Well } \\
\text { no. }\end{array}$ & $\begin{array}{l}\text { Land- } \\
\text { surface } \\
\text { altitude }\end{array}$ & $\begin{array}{l}\text { Well } \\
\text { depth }\end{array}$ & $\begin{array}{l}\text { We11 } \\
\text { no. }\end{array}$ & $\begin{array}{l}\text { Land- } \\
\text { surface } \\
\text { altitude }\end{array}$ & $\begin{array}{r}\text { Well } \\
\text { depth }\end{array}$ \\
\hline S 6678 & 1 & 124 & S 19565 & 44 & 119 \\
\hline S 7148 & 170 & 144 & S 20300 & 75 & 232 \\
\hline S 8128 & 144 & 385 & S 20305 & 10 & 448 \\
\hline S 8205 & 235 & 203 & S 20369 & 120 & 312 \\
\hline S 8861 & 290 & 246 & S 20566 & 26 & 775 \\
\hline S 8943 & 240 & 268 & s 20635 & 41 & 704 \\
\hline S 9067 & 85 & 300 & S 20924 & 10 & 485 \\
\hline S 11279 & 5 & 408 & S 20955 & 22 & 630 \\
\hline S 11428 & 5 & 180 & S 21009 & 45 & 432 \\
\hline S 11538 & 12 & 120 & S21362 & 158 & 565 \\
\hline S 12079 & 141 & 445 & S21375 & 18 & 501 \\
\hline S 12379 & 18 & 75 & S 22015 & 140 & 722 \\
\hline S 12441 & 3 & 162 & S 22169 & 5 & 433 \\
\hline S 12628 & 5 & 159 & S 22278 & 60 & 184 \\
\hline S 12873 & 82 & 388 & S 22351 & 21 & 558 \\
\hline S 13591 & 170 & 309 & S 22494 & 50 & 120 \\
\hline S13854 & 10 & 319 & S 22577 & 61 & 907 \\
\hline S 14326 & 70 & 225 & $\mathrm{~S} 22910$ & 125 & 946 \\
\hline S 14825 & 140 & 193 & S 23058 & 40 & 217 \\
\hline S 14904 & 3 & 238 & S23059 & 105 & 204 \\
\hline S 14940 & 3 & 191 & S 23183 & 61 & 500 \\
\hline S 15008 & 5 & 479 & S 23445 & 110 & 610 \\
\hline S 15212 & 7 & 290 & S 23455 & 30 & 81 \\
\hline S 15539 & 20 & 315 & S 23626 & 4 & 526 \\
\hline S 16395 & 10 & 477 & S 23823 & 70 & 407 \\
\hline S 16526 & 120 & 301 & S 23848 & 50 & 634 \\
\hline S 16604 & 210 & 183 & S 24846 & 90 & 517 \\
\hline S 16936 & 75 & 211 & S 25674 & 50 & 625 \\
\hline S 17181 & 1 & 314 & S 27258 & 26 & 607 \\
\hline S 18003 & 26 & 671 & S 27739 & 140 & 925 \\
\hline S 18075 & 110 & 627 & S 28035 & 125 & 326 \\
\hline S 18473 & 65 & 660 & S 28212 & 10 & 325 \\
\hline S 19048 & 25 & 735 & S 28339 & 15 & 686 \\
\hline S 19123 & 20 & 209 & S 29491 & 25 & 499 \\
\hline S 19317 & 3 & 484 & S 29776 & 195 & 720 \\
\hline
\end{tabular}


Table 2.--Well depth and altitude data on selected wells in southern Nassau, southwestern Suffolk, and eastern Queens Counties, New York (continued)

\begin{tabular}{|c|c|c|c|c|c|}
\hline $\begin{array}{l}\text { We11 } \\
\text { no. }\end{array}$ & $\begin{array}{l}\text { Land- } \\
\text { surface } \\
\text { altitude }\end{array}$ & $\begin{array}{l}\text { Well } \\
\text { depth }\end{array}$ & $\begin{array}{l}\text { Well } \\
\text { no. }\end{array}$ & $\begin{array}{l}\text { Land- } \\
\text { surface } \\
\text { altitude }\end{array}$ & $\begin{array}{r}\text { We11 } \\
\text { depth }\end{array}$ \\
\hline S 29962 & 208 & 675 & S41342 & 130 & 663 \\
\hline S 30007 & 101 & 592 & S41344 & 79 & 693 \\
\hline S 30235 & 280 & 340 & S41513 & 108 & 719 \\
\hline S 30343 & 60 & 350 & S 42054 & 40 & 723 \\
\hline S 30421 & 125 & 270 & S42761 & 75 & 333 \\
\hline s30506 & 75 & 621 & $S 42762$ & 26 & 714 \\
\hline S 30550 & 6 & 507 & $\mathrm{~S} 42827$ & 35 & 753 \\
\hline S 31023 & 100 & 384 & S43088 & 90 & 902 \\
\hline S 31113 & 7 & 508 & S43101 & 40 & 703 \\
\hline S 31624 & 110 & 439 & $S 43516$ & 55 & 803 \\
\hline S 32412 & 110 & 900 & S44032 & 118 & 753 \\
\hline S 32501 & 26 & 632 & S44137 & 39 & 720 \\
\hline S32841 & 61 & 648 & S44186 & 165 & 673 \\
\hline S33005 & 33 & 681 & S45220 & 10 & 724 \\
\hline$S 33230$ & 240 & 360 & $S 45347$ & 130 & 643 \\
\hline S 33379 & 134 & 1,580 & S45839 & 40 & 726 \\
\hline S 34021 & 260 & 710 & S46235 & 40 & 721 \\
\hline S 34063 & 200 & 736 & S47672 & 100 & 734 \\
\hline S 34100 & 53 & 711 & 547711 & 25 & 221 \\
\hline S 35063 & 13 & 710 & S48422 & 95 & 735 \\
\hline S 35669 & 70 & 118 & S 50630 & 20 & 243 \\
\hline S 35670 & 45 & 172 & S51609 & 99 & 729 \\
\hline S 36460 & 76 & 611 & S51673 & 25 & 778 \\
\hline S36714 & 63 & 354 & S 52236 & 80 & 98 \\
\hline S37140 & 35 & 312 & S53274 & 109 & 800 \\
\hline S 37144 & 76 & 202 & S 53339 & 50 & 798 \\
\hline S 37145 & 98 & 210 & S54099 & 170 & 703 \\
\hline S 37494 & 60 & 622 & S54155 & 38 & 721 \\
\hline S37681 & 42 & 583 & S 54957 & 50 & 378 \\
\hline S 38035 & 132 & 450 & S 56423 & 50 & 800 \\
\hline S 38192 & 66 & 605 & S56508 & 6 & 709 \\
\hline S 39518 & 76 & 725 & S5 7008 & 111 & 635 \\
\hline S40057 & 110 & 623 & S 58708 & 132 & 423 \\
\hline S40330 & 43 & 337 & S 60127 & 132 & 489 \\
\hline 540818 & 55 & 754 & S 60812 & 38 & 488 \\
\hline
\end{tabular}


Table 2.--Well depth and altitude data on selected wells in southern Nassau, southwestern Suffolk, and eastern Queens Counties, New York (continued)

\begin{tabular}{|c|c|c|c|c|c|}
\hline $\begin{array}{l}\text { Well } \\
\text { no. }\end{array}$ & $\begin{array}{l}\text { Land- } \\
\text { surface } \\
\text { altitude }\end{array}$ & $\begin{array}{l}\text { Well } \\
\text { depth }\end{array}$ & $\begin{array}{l}\text { Well } \\
\text { no. }\end{array}$ & $\begin{array}{l}\text { Land- } \\
\text { surface } \\
\text { altitude }\end{array}$ & $\begin{array}{r}\text { Well } \\
\text { depth }\end{array}$ \\
\hline S 61664 & 28 & 763 & S 66149 & 40 & 183 \\
\hline S63311 & 130 & 802 & S 66150 & 25 & 163 \\
\hline S65196 & 69 & 124 & S66151 & 5 & 150 \\
\hline S 66132 & 100 & 140 & S66152 & 115 & 193 \\
\hline S 66133 & 63 & 161 & S66153 & 50 & 163 \\
\hline S 66134 & 50 & 150 & S 66154 & 30 & 153 \\
\hline S 66135 & 30 & 168 & S66155 & 20 & 155 \\
\hline S 66136 & 5 & 144 & S66156 & 15 & 173 \\
\hline S 66137 & 160 & 143 & S 66556 & 50 & 753 \\
\hline S 66138 & 60 & 150 & S 67074 & 70 & 832 \\
\hline S66139 & 45 & 152 & S67081 & 4 & 125 \\
\hline S66140 & 24 & 112 & S 67082 & 12 & 234 \\
\hline S66141 & 5 & 133 & S 67083 & 12 & 125 \\
\hline S 66142 & 150 & 203 & S 67084 & 9 & 205 \\
\hline S 66143 & 70 & 185 & S 67085 & 7 & 122 \\
\hline S 66144 & 55 & 143 & S 67086 & 10 & 125 \\
\hline S 66145 & 40 & 175 & S 67087 & 10 & 205 \\
\hline S 66146 & 10 & 143 & S 67088 & 10 & 225 \\
\hline S 66147 & 10 & 184 & S67197 & 64 & 763 \\
\hline S 66148 & 66 & 153 & & & \\
\hline
\end{tabular}

